\title{
Undescended testis - current trends and guidelines: a review of the literature
}

Jerzy K. Niedzielski ${ }^{1}$, Elżbieta Oszukowska², Jolanta Słowikowska-Hilczer ${ }^{3}$

\author{
${ }^{1}$ Department of Pediatric Surgery and Urology, Medical University of Lodz, Lodz, \\ Poland \\ ${ }^{2}$ Second Department of Urology, Medical University of Lodz, Lodz, Poland \\ ${ }^{3}$ Department of Andrology and Reproductive Endocrinology, Medical University \\ of Lodz, Lodz, Poland
}

Submitted: 23 January 2015

Accepted: 26 February 2015

Arch Med Sci 2016; 12, 3: 667-677

DOI: 10.5114 /aoms.2016.59940

Copyright @ 2016 Termedia \& Banach

\section{Abstract}

The best mode of undescended testis (UDT) treatment remains controversial. However, knowledge gained from randomized controlled studies and meta-analyses allowed different groups of researchers to set out guidelines on management of patients with UDT. The authors reviewed recent literature and came to the following conclusions: (1) Hormonal treatment is not recommended, considering both the immediate results (only 15-20\% of retained testes descend) and the possible long-term adverse effects on spermatogenesis. (2) Surgery is the treatment of choice; orchiopexy is successful in about $95 \%$ of UDT, with a low rate of complications (about $1 \%$ ). (3) Orchiopexy should be performed between 12 and 18 months of age, or at first contact if diagnosed later.

Key words: undescended testes, cryptorchidism, hormonal treatment, surgical treatment, fertility, malignancy.

Although we know a lot about the testicular descent in humans, there is at least as much or even more things we do not understand and cannot explain in this process, such as the optimal way and time for treatment of undescended testes (UDT), which has been a matter of debate for decades. Reaching a consensus in the scientific community is not easy, especially in the medical field, where one needs to have long enough follow-up in a randomized controlled study including big enough, standardized groups of patients. Over the last decade great work has been done by researchers from different European countries to accumulate and summarize the knowledge on UDT. It has led to the formulation of the conclusions of the Nordic consensus [1], the German consensus [2] and finally the European Society for Paediatric Urology (ESPU) and European Association of Urology (EAU) [3] as well as the American Urological Association (AUA) guidelines on the management of UDT [4].

Benefiting from a comfortable position of working in a team of a pediatric surgeon, endocrinologist, urologist and andrologist, we decided to describe an algorithm on managing a boy with UDT based on a review of the current literature, including available consensuses and guidelines.

\author{
Corresponding author: \\ Prof. Jerzy K. Niedzielski \\ MD, PhD \\ Department of Pediatric \\ Surgery and Urology \\ Medical University of Lodz \\ 36/50 Sporna St \\ 91-738 Lodz, Poland \\ Phone: +48 426177711 , \\ +48502133992 \\ E-mail: jerzy.niedzielski@ \\ umed.lodz.pl
}




\section{Definition of undescended testes}

Terms such as undescended testis, retentio testis, cryptorchidism, and maldescended testis describe a testis that is not normally located at the bottom of the scrotum [5].

The UDT may be situated along its normal route of descent or in an ectopic position.

- Cryptorchid/undescended: testis neither resides nor can be manipulated into the scrotum.

- Ectopic: aberrant course of descent, usually after leaving inguinal canal: femoral, pubopenile, perineal or crossed scrotal [6].

- Retractile: testis can be manipulated into scrotum where it remains without tension.

- Gliding: testis can be manipulated into upper scrotum but retracts when released [7].

- Acquired: testis previously descended or after orchiopexy or other inguinal surgery (hernia), then "ascends" spontaneously $[8,9]$.

\section{Prevalence of undescended testes}

About one third of premature boys have a UDT at least on one side, compared to $2-8 \%$ incidence in full-terms boys, which makes cryptorchidism the most common anomaly in boys [5]. Congenital UDT descend spontaneously mostly during the first months of life. Between 2 and 4 months of age pituitary gonadotropins stimulate a sudden increase in testosterone secretion which peaks at about 3-6 months. This brief surge of gonadotropins and androgens is known as a "mini-puberty" $[10,11]$. Thus, a lower incidence of $1-2 \%$ is reported from 3 to 12 months of life [5]. According to the literature, spontaneous descent of the testis after 6 months of age occurs very rarely; therefore the "watchful waiting" strategy is not justified in these boys [9, 12].

Unilateral UDT is four times more common than bilateral [13]. Analysis of 2150 orchiopexies reported in seven studies from Denmark revealed $23 \%$ incidence of bilateral, $46 \%$ of right sided and $31 \%$ of left sided UDT [14].

\section{Classification of undescended testes}

For practical reasons, in order to qualify patients for treatment and to decide on the kind of treatment, UDT is differentiated between:

- congenital and acquired,

- palpable and non-palpable,

- unilateral or bilateral [2, 4, 5, 15, 16].

About $80 \%$ of UDT are palpable and $20 \%$ are non-palpable [16]. Palpable UDT are located along the inguino-scrotal descent route. The term non-palpable means that the testis was not found during the patient's examination. In that case we deal with an abdominal testis or with lack of testis (anorchia). Anorchia can be a result of testicular agenesis or testicular atrophia. The cause of testicular agenesis is usually unknown, but in some cases genetic mutations, responsible for testis differentiation during the fetal period of life, are detected [17]. In the case of testicular agenesis, no testis, blood vessels or vas deferens are present during the exploratory laparoscopy. In these cases disorders of development of male sex organs are observed. If rudimentary vessels and vas deferens can be seen during laparoscopy, it suggests a case of testicular atrophy being a result of a prenatal testicular vascular accident. Bilateral anorchia, or embryonic testicular regression (vanishing testis syndrome), is defined as the absence of testes in a $46, X Y$ individual with a male phenotype $[18,19]$. It affects one in 20,000 male births and occurs in $1 / 177$ cases of cryptorchidism [20].

For research reasons and for the benefit of future studies on UDT, as well as to allow the possibility to compare results of treatment studies, more precise classification of testis maldescent regarding testis position is suggested:

- high or low abdominal,

- inguinal,

- supra or high scrotal,

- ectopic $[2,5,13,15]$.

\section{Embryology - formation of a testis}

A brief review of testis formation is essential to understand how disorders of this process could lead to seemingly diverse abnormalities, such as cryptorchidism, abnormal spermatogenesis, tumors of the testis or male excurrent duct system, or aplasia of male genitalia [21, 22].

The sex-determining region of the genome is located on the short arm of the $Y$ chromosome and is called the $S R Y$ (sex-determining region $Y$ ) gene. $S R Y$ is an intronless sex-determining gene on the $Y$ chromosome in the therians (placental mammals and marsupials), and mutations in this gene lead to a range of sex-related disorders with varying effects on an individual's phenotype, e.g. cryptorchidism. SRY gene expression by somatic mesenchymal cells of the forming gonad generates production of SRY protein, also known as the testis-determining factor (TDF). From the sixth week of gestation, the SRY protein initiates a cascade of events leading to differentiation of male reproductive structures. Without these events, the embryo follows the default development pathway, forming female internal and external genitalia [23-26].

\section{Testis descent}

In most mammals, the testis descends from the abdomen to an extracorporeal position (scrotum) to find a lower ambient temperature for normal 
spermatogenesis. The difference between scrotal temperature and body temperature in adult males is $2-4^{\circ} \mathrm{C}$ [27]. The testicular descent occurs in two stages with different anatomical mechanisms and hormonal controls: the trans-abdominal phase and the inguino-scrotal phase [28, 29].

The trans-abdominal phase lasts from the $8^{\text {th }}$ to $15^{\text {th }}$ week and the inguino-scrotal phase lasts from the $25^{\text {th }}$ to $35^{\text {th }}$ week of gestation. An interval of around 10 weeks of inactivity between the phases is not readily explained [28, 29].

\section{Phase I - Trans-abdominal phase $\left(8-15^{\text {th }}\right.$ week of gestation)}

The testis is attached to the diaphragm by the cranio-suspensory ligament that degenerates in the male fetus, induced by testosterone, and releases the cranial end of the testis. This is the only role played by androgens in phase I. Simultaneously the gubernaculum attached to the caudal end of the testis thickens and anchors the testis to the inguinal region and seemingly relocates it while the abdominal cavity is enlarging [29]. Thickening of the gubernaculum seems to be controlled by insulin-like 3 protein (INSL3) and its receptor leucine-rich repeat-containing G protein coupled receptor 8 (LGR8), which was observed in mice $[29,30]$. INSL3 is produced by the Leydig cells and is partly controlled by human chorionic gonadotropin (hCG) and luteinizing hormone (LH) [31].

However, in cryptorchid boys mutations of the INSL3 gene are uncommon, probably because in the trans-abdominal phase the testis stays attached by the gubernacula to the inguinal region and its descent is rather feigned. Since the mechanism is simple, abnormalities in the process are infrequent [28].

Müllerian inhibiting substance/anti-Müllerian hormone (MIS/AMH) is assumed to play some role in phase I. In the persistent Müllerian duct syndrome, which is caused by genetic abnormality of $\mathrm{AMH}$ or its receptor, the testes are very mobile and may be located in an ovarian position, in an inguinal hernia together with a Fallopian tube and the uterus. However, it is likely that the cause is mechanical in nature because of the testis being attached to a Fallopian tube. However, AMH receptor-deficient mice have normal testis descent [26, 29]. The trans-abdominal phase is rarely disrupted and only about $5 \%$ of operated UDT are intra-abdominal $[5,9,12,13]$.

\section{Phase II - Inguino-scrotal phase (25-35 th week of gestation)}

The final phase of testicular descent, the inguino-scrotal descent, is regulated by a combination of hormonal and mechanical factors. This phase starts around the $25^{\text {th }}$ week of gestation and the gubernaculum reaches the scrotum at the $35^{\text {th }}$ week [28, 29]. The gubernaculum acts as a guide wire for the scrotal descent of the testis. It initially ends at the future external inguinal ring, and needs to reach the bottom of the scrotum, which requires a very complex and precarious migratory mechanism. Most of the descending testes are stopped at this particular moment [5, 9, 12, 13].

The androgens may masculinize the sensory branches of the genitofemoral nerve, which then releases a neurotransmitter, calcitonin gene-related peptide (CGRP), to control growth and elongation of the gubernacula [32]. The gubernaculum contains high levels of androgen receptors and is considered the primary site of androgen action in testicular descent. The diameter of the gubernaculum reaches its maximum during the seventh month, which induces widening of the inguinal canal. Simultaneously, the tip of the processus vaginalis actively elongates to create a peritoneal diverticulum which will allow the intra-abdominal testis to leave the abdomen [33]. The increased abdominal pressure, caused by the growth of viscera, pushes the testis and epididymis down through the inguinal canal and the processus vaginalis. It is estimated that the distance covered during this phase of testicular migration is around $5-10 \mathrm{~cm}$, from the internal inguinal ring to the bottom of the scrotum. Once in the scrotum, the testis and the epididymis are covered by the peritoneal pouch of the prolonged processus vaginalis, whose distal part becomes the tunica vaginalis testis and the connection to the peritoneum involutes. Its incomplete involution may be a cause of the ascending testis. The gubernaculum shrinks, becomes more fibrous and persists as the scrotal ligament [28, 29, 33].

\section{Etiology of undescended testes}

The etiology of cryptorchidism remains largely unknown, and several hypotheses have been proposed. Among others, placental dysfunction with reduced $\mathrm{hCG}$ secretion may be responsible for hormonal and other disturbances during the fetal period of life [33]. According to some researchers, the primary fault lies in the testis itself [21].

Risk factors of UDT [34]:

- intrauterine growth restriction (IUGR),

- prematurity -incidence in premature infants 30\%,

- first- or second-born boys,

- perinatal asphyxia,

- Cesarean section,

- toxemia of pregnancy,

- congenital subluxation of hip,

- seasonal (especially winter).

The environmental factors such as persistent organochlorine compounds, mono-esters of the phthal- 
ates, maternal smoking and maternal diabetes mellitus also increase the risk of cryptorchidism [35, 36]. Familial occurrence of UDT has also been described [37]. Cryptorchidism occurs in many syndromes and in caudal developmental field defects [5].

The etiological factors of UDT can be traditionally grouped $[5,12,13]$ as:

a) anatomical:

- anomalies of the testis, epididymis and vas deferens [38],

- improper attachment of the gubernaculum,

- patent processus vaginalis and inguinal hernia (hernias are found in $90 \%$ of UDT),

- anomalies of the inguinal canal.

b) hormonal [5, 29, 32]:

- deficient GnRH (gonadotropin releasing hormone) and/or gonadotropin production or insensitivity of GnRH or LH receptors,

- deficient androgen production or insensitivity of androgen receptor,

- deficient AMH production or insensitivity of $\mathrm{AMH}$ receptor,

- deficient INSL3 production or insensitivity of INSL3 receptor,

- deficient CGRP production (disorder of genito-femoral nerves) or insensitivity of CGRP receptor.

c) genetic (can influence both anatomical and hormonal factors):

- androgen receptor gene mutations (chromosome X), i.e. an increased GGN (polyglycine) [39] or CAG (polyglutamine) repeat length [39],

- $5 \alpha$-reductase gene mutations (chromosome 2) - rare in UDT [40],

- HOXA10 gene mutations (chromosome 7) rare in UDT [41],

- heterozygous mutations of $\operatorname{lns} 13$ and $\operatorname{Lgr} 8$ genes (chromosome 19) - rare in UDT [30],

- an increased incidence of a polymorphic allele of SF-1 (steroidogenic factor 1), which has a reduced transcription activity. SF-1 may affect expression of INSL3 and LGR8 [42].

Despite the etiological factors mentioned above, in most cases of UDT they remain unknown. However, in some cases of cryptorchidism its cause seems to be a combination of genetic, anatomical, hormonal and environmental factors [5, 10, 22, 30, 32].

\section{Pathophysiology of undescended testes}

\section{Increased temperature}

Maintenance of testicular temperature of $2-7^{\circ} \mathrm{C}$ below body temperature is essential for spermatogenesis $[13,43]$. There are five unique anatomical features of the scrotum important for thermoregulation [43]:

- thin scrotal skin, often hairless, numerous sweat glands,

- tunica dartos,
- pampiniform plexus,

- cremaster muscle,

- absence of adipose tissue.

A decrease of the rectoscrotal temperature gradient by just $1-2^{\circ} \mathrm{C}$ is sufficient to experimentally suppress spermatogenesis [44]. Varicocele and UDT may cause male impaired fertility associated with abnormal spermatogenesis $[45,46]$. The UDT develops in the increased ambient temperature of the abdomen or the inguinal canal. This thermal injury is mediated by reactive oxygen species and certain heat-shock proteins, which damage germ cells as well as Sertoli cells [43, 47]. Orchiopexy even if performed as early as before 1 year of age may not prevent postnatal morphological changes in the testis $[43,48]$.

\section{Impaired spermatogenesis and infertility}

Spermatogenesis is the process by which sperm cells are produced. It takes place in the seminiferous tubule. The fetal/neonatal gonocytes transform into adult dark (Ad) spermatogonia between 3 and 9 months of age, stimulated by the surge of gonadotropins and testosterone (mini-puberty). Next, after a period of inactivity, primary spermatocytes form at about 5-6 years of life, and spermatids appear at about 10-11 years, with the onset of full spermatogenesis [49]. Not all neonatal gonocytes transform into Ad spermatogonia. The remaining gonocytes undergo involution by apoptosis, clearing the testis of any undifferentiated, pluripotential fetal germ cells, so that by 2 years of age there are none left in the testis [11,50].

Undescended testes impairs both transformation of the gonocytes into Ad spermatogonia and programmed germ cell death. The inhibition of this transformation leads to a deficient pool of stem cells for post-pubertal spermatogenesis and infertility, while persisting undifferentiated germ cells may become malignant after puberty [11, 29, 50]. Defective transformation of gonocytes into Ad spermatogonia correlates with abnormal sperm counts after puberty [50].

Numerous long-term outcome studies have shown that cryptorchidism in the past was associated with a $30-60 \%$ risk of infertility or lack of germ cells in adult men $[51,52]$. The number of germ cells was decreased in about one-fourth of cryptorchid newborns [52]. It was found that there were signs of early degeneration in the testis on electron microscopy at about 12 months of age [53]. Lack of germ cells has been reported from 12, and especially from 18 months of age, and therefore surgery has been recommended before 12 or 18 months of age $[54,55]$.

The risk of infertility in adulthood is significantly higher in patients with bilateral UDT. Approximately $10 \%$ of infertile men have a history of cryptorchi- 
dism and orchidopexy [56]. If left untreated, bilateral UDT causes azoospermia in $89 \%$ of adult men. If bilateral orchiopexy was performed in childhood, about $28 \%$ of these men have at least 20 million sperm $/ \mathrm{ml}$ of ejaculate. About $50 \%$ of men with untreated unilateral UDT have at least 20 million sperm $/ \mathrm{ml}$ as compared to about $70 \%$ after orchiopexy. Surgery significantly improved sperm count in uni- and bilateral cases, even though patients of the discussed report were older than 2 years at orchiopexy [5]. Although men with a history of unilateral UDT have a lower fertility rate, they have the same paternity rate as the normal population. Adults with a history of bilateral UDT have a lower fertility and paternity rate $[3,56]$.

\section{Risk of testicular germ cell tumors (TGCT)}

The pathogenesis of malignant transformation of fetal germ cells into testicular intraepithelial neoplastic cells (TIN) or testicular carcinoma in situ (CIS) cells has not been elucidated yet. Nevertheless, a series of epidemiological studies have linked the majority of risk factors with intra-uterine and perinatal testicular development, and several of these factors have also been associated with cryptorchidism [57]. One hypothesis is that abnormally high temperature in which UDT develops impairs both transformation of the neonatal gonocytes into the Ad spermatogonia and apoptosis of remaining gonocytes, allowing some to persist to become a possible source of CIS and malignancy after puberty [11, 29]. Carcinoma in situ is more common in men with a history of cryptorchidism, with the prevalence of $2-3 \%$ in adult patients $[4,58]$. The incidence of CIS is higher in men with macroscopic testicular atrophy [11], with bilateral cryptorchidism, with intra-abdominal testes, with abnormal genitalia or with an abnormal karyotype $[57,59]$. In boys with unilateral UDT, the contralateral descended testis has a slightly increased risk of cancer [60].

There is clinical evidence from long-term follow-up studies that cryptorchidism in the past is associated with a 5 - to 10 -fold increase in TGCT $[57,61]$. Testicular germ cell tumors are common, affecting $1 \%$ of young men [58]. They have a prevalence of $1 \%$ of all neoplasms in men, with the peak incidence between 20 and 30 years of life. About $10 \%$ of all cases of TGCT develop in men with a history of cryptorchidism [57, 59]. The risk of TGCT is greater in intra-abdominal and bilateral UDT [59, 62]. Seminoma and embryonal carcinoma are the most common TGCT in UDT. Gonadoblastoma is the most common in some disorders of sex development (DSD) which also present UDT associated with gonadal dysgenesis $[57-59,63]$. The risk of TGCT is significantly decreased if orchiopexy for UDT is performed before puberty [64]. Now, it is recommended that orchiopexy be performed as early as 6-12 months of age to ensure that optimal germ cell development occurs during the first year of life [2, 29, 55].

\section{Testicular dysgenesis syndrome}

A unifying hypothesis has been proposed to group hypospadias, TGCT, reduced sperm concentration, and cryptorchidism, as the testicular dysgenesis syndrome (TDS). These conditions are thought to have a common origin in prenatal testicular maldevelopment, which affects Leydig, Sertoli and germ cell differentiation [21]. Undescended testes frequently contain distorted tubules, immature Sertoli cells or microcalcifications, indicating testicular dysgenesis [21, 61]. Testicular dysgenesis syndrome may be caused by genetic disorders as well as by environmental factors [21]. Non-cryptorchidism does not guarantee occurrence of other elements of TDS [22]. In TDS, the gonads have failed to fully differentiate and the appearance of the external genitalia can range from obviously female to obviously male. Disorders of testicular organogenesis may range from a streak gonad to an underdeveloped testis. The karyotype may be normal male, but frequently a mosaic of $45, X / 46, X Y$ can be found [65]. Cryptorchidism and testicular dysgenesis or presence of streak gonads may also be seen in chromosome 9p deletion, campomelic dysplasia (SOX9 mutation) and mutations in the WT-1 or SRY gene $[4,66]$.

\section{Acquired cryptorchidism. Ascending testis}

After birth, the distance from the internal inguinal ring to the scrotum increases from 4-5 to 8-10 cm in puberty, which means that the spermatic cord must double in length. Failure of this elongation may be the cause of ascending testis - acquired UDT [11, 32]. It is still unclear whether the ascending testis is the result of this mechanical obstacle, or is also linked to some cause of androgen deficiency [29]. Ascent of the testis may explain the significant number of orchiopexies performed at the age of 5-10 years when the ascent of testis occurs [9]. It also explains why the number of performed orchiopexies is higher than the incidence of UDT in the population $[8,14]$.

Since men with untreated, acquired UDT have no increased testicular germ cell neoplasia (TGCN) risk, an expectative policy - waiting for spontaneous descent at puberty - is recommended rather than routine orchidopexy [67].

\section{Diagnostics of undescended testes}

\section{Medical history}

The interview should include the data on the course and duration of pregnancy, medication 
used and exposure to environmental toxins, as well as birth weight, position of testes at birth, other defects and diseases of the child and family history $[8,9,12]$.

\section{Physical examination}

Palpation is a basic technique to examine UDT It allows differentiation between palpable and nonpalpable, retractile and gliding testes [7]. It is mandatory to assess the appearance of external genitalia to exclude DSD. A patient should be examined in both supine and standing (older boys) position in a warm room, with warm hands.

Gonads should be carefully examined for size, turgor, any palpable paratesticular anomalies, and the presence of hernia or hydrocele $[13,15,33,38]$.

\section{Imaging}

Accurate assessment of the position of the UDT and its volume compared with the contralateral, healthy testis gives the surgeon a basic knowledge in cryptorchid boys. Different imaging techniques have been evaluated for the assessment of UDT $[68,69]$ :

- ultrasonography (US) - good to assess the size of inguinal testes, less reliable for abdominal testes,

- computed tomography (CT) - may be helpful for bilateral impalpable testes; performed under general anesthesia in young children,

- magnetic resonance imaging (MRI) - may be helpful for bilateral impalpable testes; performed under general anesthesia in young children; the least invasive, most expensive,

- venography, angiography - invasive, difficult to perform, high rate of complications; not useful in children.

Of the above imaging techniques, US with a high resolution transducer (>7.5 MHz) offers the greatest accuracy in assessment of $100 \%$ of palpable and of $84 \%$ of non-palpable UDT (with a sensitivity of $76 \%$ and a specificity of $100 \%)[68,69]$.

US of the inguinal testis allows one to assess parenchymal structure and size of the UDT. Three dimensions of both testes should be recorded and used to calculate testicular volume (TV): TV $\left[\mathrm{cm}^{3}\right]=0.52 \times$ width $[\mathrm{cm}] \times$ length $[\mathrm{cm}] \times$ height $[\mathrm{cm}]$. The testicular atrophy index (TAI) of the affected testicle can be calculated as [70]: TAI (\%) = (contralateral TV - affected TV)/contralateral TV $\times$ $100 \%$. Testicular atrophy index is a valuable and objective tool for assessment of the state of development of the testis at every stage of UDT treatment. It helps to make a decision on continuing observation or performing orchiopexy in boys with retractile or acquired UDT, and allows monitoring of the results of treatment [70].

\section{Treatment}

There are two basic modes of treatment of UDT used for many years and accepted all over the world: hormonal and surgical. They can be used alone or as complementary methods [1-9]. The main goal of UDT treatment is to pull the testis down to the scrotum. This should be done for the following reasons:

- to prevent the impairment of spermatogenesis, - to prevent, or at least decrease, the risk of TGCN, - to facilitate future examination of the testicle (palpation, US),

- to correct the inguinal hernia frequently accompanying UDT,

- to minimize the risk of torsion of the testis, which is increased in infants with UDT due to the greater mobility of the inguinal testis and patent processus vaginalis. Diagnosis and surgery are often delayed, with a high rate of orchiectomies [71].

\section{Hormonal treatment}

The hormonal treatment of UDT is based on the hypothesis of deficiency of the hypothalamic-pituitary-testicular axis at the end of gestation or shortly after birth, and hence the lack of the 'mini-puberty'. Hormonal therapy is usually carried out using hCG, gonadotropin releasing hormone $(\mathrm{GnRH}$, luteinizing hormone releasing hormone - LHRH) or a combination of both. It can be administered as a neoadjuvant therapy prior to the orchiopexy or as a supplementary treatment after early surgery for UDT [50].

The first method of hormonal therapy was hCG administration, advocated in boys with UDT in the 1950s, with some of the treatment series dated as early as the 1930s [72, 73]. The hCG is produced by the syncytiotrophoblast and stimulates testicular Leydig cells to produce testosterone. As androgen takes part in the process of testicular descent it seems justified to stimulate its production. Evidence for the beneficial role of the hormonal therapy to improve testis position has been reported [74]. Treatment with hCG is still used; however, in the 1990s and 2000s critical studies and metaanalyses of UDT treatment with hCG and its adverse effect on future reproductive function in adults appeared $[75,76]$.

GnRH therapy was first administered in boys with UDT in the 1970s [77]. GnRH is produced by the hypothalamus and stimulates the anterior pituitary gland to secrete $\mathrm{LH}$ and follicle-stimulating hormone (FSH). FSH stimulates the proliferation and differentiation of spermatogonia [78]. GnRH therapy may improve germ cell number, maturation and later semen parameters in boys with UDT $[75,76]$. The combined administration of $\mathrm{GnRH}$ 
and hCG in boys younger than 1 year can be beneficial for spermatogonial transformation and proliferation [79], with a success rate of about $20 \%$.

The dose of hormonal therapy is usually as follows [2, 3]:

$-\mathrm{GnRH}-3 \times 400 \mu \mathrm{g} /$ day (i.e. $3 \times$ daily one puff of $200 \mu \mathrm{g}$ into each nostril) over 4 weeks as nasal spray,

- hCG - $50 \mathrm{IU} / \mathrm{kg}$ body weight in intramuscular injection twice a week for 3-5 weeks (total dosage of 6,000-9,000 IU).

\section{Surgical treatment (orchiopexy)}

The first successful relocation of the testis (orchiopexy) in a 3-year-old boy with an ectopic testis was described in 1879 [80]. It became a routine procedure in the 1950s and early 1960s [81, 82].

Nowadays, the surgical therapy for the palpable UDT is orchiopexy with creation of a subdartos pouch [82]. Fixation is achieved by the scarring of the everted tunica vaginalis to the surrounding tissues. The Bianchi single high scrotal incision is an optional technique for orchiopexy in boys with UDT situated distal to the external inguinal ring [83]. The retroperitoneal dissection is however crucial for the success of any surgical procedure $[82,83]$.

When the testis is non-palpable, diagnostic laparoscopy through an umbilical port is the procedure of choice. If the testicular vessels exit through the internal ring, an inguinal incision allows one to locate the testis (orchiopexy) or its remnants (removal and histopathologic examination) $[16,84]$.

Approximately half of intra-abdominal testes are located close to the internal ring, and the Fowler-Stephens (F-S) maneuver (also called the Fowler-Stephens operation) is recommended then as a routine procedure [85]. It involves laparoscopic intraperitoneal ligature and division of the testicular vessels, which leaves the testis dependent on the vasal, cremasteric and gubernacular arteries (evidence level IV) [85]. In the two-stage F-S procedure, a 6-month delay is recommended before inguinal orchiopexy to allow the collateral circulation to develop. The single-stage F-S operation is rarely performed as it leaves the collateral circulation no time to form and puts the testis at higher risk of atrophy $[16,84,85]$.

Bilateral non-palpable testes create a few clinical situations. Both testes can be present in the intra-abdominal position, or one or both testes can be missing (anorchia) [18-20]. Positive testosterone response to hCG stimulation, low serum levels of FSH and normal levels of inhibin B confirm the presence of functioning testicular tissue. Diagnostic laparoscopy is performed to determine surgical therapy in the same manner as for unilateral, non-palpable undescended testes. No re- sponse to hCG stimulation, increased serum levels of FSH and very low levels of inhibin B in boys with bilateral non-palpable testes prove that testicular tissue is not present [86].

\section{Timing of orchiopexy}

In the 1950s, orchiopexy was recommended in boys aged 10-15 years [81], in the 1970s in 5-6-year-old boys [87]. During the 1970s and early 1980s the age of orchiopexy declined to 2 years of age [53]. Currently orchiopexy is recommended between 6 and 12-18 months [13-15]. The main goal of this timing of orchiopexy is to prevent the impairment of spermatogenic function and decrease the risk of TGCT in adult life. Although many researchers have reported the beneficial role of early orchiopexy in preventing these problems, there is still a need for large prospective studies providing more clinical evidence $[52,53$, 55, 56, 64].

Life and clinical practice verify all the recommendations, and numerous studies show that the mean age of boys with UDT at the time of surgery is well above this recommended age and has not decreased significantly during the last decade $[74,88]$. However, the risk of poor sperm count is probably independent of the age of surgery, but it is correlated with the number of gonocytes and spermatogonia [55].

\section{Results of treatment and prognosis}

The success rate of hormonal therapy (scrotal position of testis) varies from $8 \%$ to $60 \%$, less if retractile testes are excluded. The meta-analyses revealed an overall efficacy of around $20 \%$, which decreases with time to about $15 \%$ after re-ascent of some testes $[75,76]$. This should be compared with about $95 \%$ efficacy of primary orchiopexy [75].

Success of the operative treatment of UDT is defined as scrotal position and lack of atrophy of the testis [1-3, 74, 81-83]. It depends on the type of UDT (palpable and non-palpable), the operative procedure performed and the age at time of surgery. The result of the treatment should be evaluated at least 1 year postoperatively and in childhood is based mostly on clinical evaluation (palpation and US).

Assembled data from 64 reports with a total of 8425 UDT revealed the following success rates of orchiopexy [89]:

- by testis position: $74 \%$ for abdominal, $82-87 \%$ for inguinal testes,

- by procedure: $89 \%$ for inguinal, $67 \%$ for F-S, $77 \%$ for staged F-S, $84 \%$ for microvascular orchiopexy.

In the 2000s, success of orchiopexy reported in the literature was $[16,90]$ :

- over $95 \%$ for inguinal testes, 
- 85-90\% for abdominal testes, with one- or twostage F-S orchiopexy, both with open surgical or laparoscopic technique.

However, having a palpable testis in the scrotum does not ensure its normal function, which means normal hormone production and normal spermatogenesis [1-3]. Assessment of the fertility potential is an additional parameter of the UDT treatment result in adulthood $[52,53]$.

\section{Complications of treatment}

Temporary side-effects of hCG treatment have been observed, including growth of the penis, pubic hair, pain in the groin and the injection site, erection pain, and behavioral problems: hyperactivity and aggression [91]. Inflammation-like morphological changes occur in the testis after the hCG treatment [92]. But, most importantly, it has been demonstrated that treatment with hCG is followed by an increase in germ cell apoptosis, which in turn is associated with smaller testis volume and higher FSH levels in adulthood [92, 93]. The greatest harm of hormonal treatment may be caused at 1-3 years of age [94].

Orchiopexy has a rather low (about 1\%) risk of complications [81-83]. They can be classified as follows:

Intraoperative (rare):

- ilioinguinal nerve injury,

- damage to the vas deferens.

Postoperative early:

- hematoma formation,

- wound infection.

Postoperative late:

- testicular atrophy,

- testicular retraction (ascent, acquired UDT),

- postoperative torsion (either iatrogenic or spontaneous).

The most serious of these complications is testicular atrophy resulting in loss of a testis. Devascularization and testicular ischemia are usually a result of excessive skeletonization of the spermatic cord and use of too forceful electrocautery. The analysis of the available literature reveals an atrophy rate of up to $8 \%$ for palpable and of up to $25 \%$ for non-palpable testes $[74,89]$.

Ascent of the testis after orchiopexy (recurrent or acquired UDT) is a well-known complication $[8,9]$. In most cases it is a result of inadequate repair of inguinal hernia or patent processus vaginalis, insufficient retroperitoneal dissection and, most importantly, insufficient dissection of the cremasteric fibers $[89,90]$. During routine orchiopexy the attachment of the gubernaculum should be released to allow identification of the testicle. During subsequent dissection, after identification of the ilioinguinal nerve, the cremasteric fibers and hernial sac should be carefully separated from the cord structures. After the sac is divided, as in routine hernia repair, the cremasteric fibers should be removed, in our opinion, to prevent postoperative ascent of the testis $[89,90]$.

Reoperation for both atrophy and ascent should not be scheduled earlier than 6 months after the first operation [2]. The atrophic testis or its remnants should be removed and examined by a pathologist to prevent TGCT development.

\section{Testicular biopsy}

Biopsy of UDT for CIS detection is generally not recommended in childhood. Intraoperative testicular biopsy in children is controversial and at present reserved for use in patients with ambiguous genitalia, chromosomal disorders or as part of clinical studies [1-3].

It is difficult to estimate the risk-to-benefit ratio of this procedure, especially taking into consideration the potential risk of worsening the function of an already compromised testis. Nevertheless, recent reports show that testicular biopsy in prepubertal boys can predict future sperm count and identify preinvasive CIS without causing damage resulting in presence of antisperm antibodies or testicular microlithiasis in adulthood [95]. It has been suggested that testicular biopsy at the time of orchiopexy is a risk factor for overt TGCT in postpuberty [59]. However, no correlation between the biopsy and subsequent TGCT was found in a large study of 830 boys with UDT undergoing routine biopsy [96]. On the other hand, alternative diagnostic methods such as reliable blood tests have not been found yet, and semen analysis cannot be performed in boys [11]

\section{Take home message}

1. It is suggested to await spontaneous descent of the testis during the first 6 months of life.

2. Hormonal therapy, either in an adjuvant or neo-adjuvant setting, is not standard treatment for cryptorchidism. Patients have to be evaluated on an individual basis [3].

3. Surgical intervention (orchiopexy) is the primary approach in boys with UDT [1-4]. It should be performed at the latest by 12-18 months of age or upon diagnosis in older boys. Every UDT should be brought to the scrotum as early as possible, regardless of its primary dimensions and position, using an appropriate surgical technique (see "Surgical treatment" section).

4. Boys with a unilateral non-palpable testis should undergo diagnostic laparoscopy followed by inguinal exploration or a two-stage F-S procedure. In boys with bilateral non-palpable testes surgical treatment should be preceded by hormonal tests (see "Surgical treatment" section). 
Further management after orchiopexy as in point 5 below.

5. Boys after orchiopexy need US evaluation (TV and TAl measurement) repeated every 12 months. TAI may indicate the method of further treatment:

- TAl 0-25\% - follow-up until 18 years, then hormonal tests and semen analysis,

- TAl 25-49\% - follow-up until 18 years, then hormonal tests, semen analysis and testicular biopsy,

- TAI $\geq 50 \%$ - biopsy of the diminished testis.

Results of histopathological evaluation revealing testicular dysgenesis or atrophy are decisive for orchidectomy, regardless of the age of the patient.

6. Boys with retractile and acquired testes usually do not need medical or surgical treatment but require close follow-up until puberty. However, US should be performed every 12 months. In the case of a decrease in TV (TAI > 25\%), orchiopexy is necessary.

Further management after orchiopexy as in point 5 above.

\section{Conflict of interest}

The authors declare no conflict of interest.

\section{References}

1. Ritzen EM, Bergh A, Bjerknes R, et al. Nordic consensus on treatment of undescended testes. Acta Paediatr 2007; 96: 638-43.

2. Leitlinie der Deutschen Gesellschaft für Kinderchirurgie, der Deutschen Gesellschaft für Urologie und der Deutschen Gesellschaft für Kinderund Jugendmedizin, vertreten durch die Arbeitsgemeinschaft für pädiatrische Endokrinologie. APE 2008; Hodenhochstand Maldeszensus testis. www.uni-duesseldorf.de/AWMF/ II/006-022.htm

3. Tekgül S, Dogan HS, Hoebeke P, et al. Pediatric Urology. European Society for Paediatric Urology, European Association of Urology. Guidelines on Paediatric Urology 2014. www.uroweb.org/fileadmin/user upload/Guidelines/ Paediatric\%20Urology.pdf

4. Kolon TF, Herndon CDA, Baker LA, et al. Evaluation and treatment of cryptorchidism: American Urological Association (AUA) Guideline. 2014. https://www.auanet.org/ education/guidelines/cryptorchidism.cfm

5. Virtanen HE, Bjerknes R, Cortes D, et al. Cryptorchidism: classification, prevalence and long-term consequences. Acta Paediatr 2007; 96: 611-6.

6. Ramareddy RS, Alladi A, Siddappa OS. Ectopic testis in children: experience with seven cases. J Pediatr Surg 2013; 48: 538-41.

7. Ferro F, Lais A, Matarazzo E, Capozza N, Caione P. Retractile testis and gliding testis. Two distinct clinical entities. Minerva Urol Nefrol 1996; 48: 145-9.

8. John Radcliffe Hospital Cryptorchidism Study Group. Cryptorchidism: a prospective study of 7500 consecutive male births 1984-88. Arch Dis Child 1992; 67: 892-9.

9. Barthold JS, Gonzalez R. The epidemiology of congenital cryptorchidism, testicular ascent and orchiopexy. J Urol 2003; 170: 2396-401.
10. Job JC, Toublanc JE, Chaussain JL, Gendrel D, Garnier P, Roger M. Endocrine and immunological findings in cryptorchid infants. Horm Res 1988; 30: 167-72.

11. Hutson JM, Li R, Southwell BR, Petersen BL, Thorup J, Cortes D. Germ cell development in the postnatal testis: the key to prevent malignancy in cryptorchidism? Front Endocrinol (Lausanne) 2013; 3: 176.

12. Berkowitz GS, Lapinski RH, Dolgin SE, Gazella JG, Bodian CA, Holzman IR. Prevalence and natural history of cryptorchidism. Pediatrics 1993; 92: 44-9.

13. Ritzén EM. Undescended testes: a consensus on management. Eur J Endocrinol 2008; 159 Suppl. 1: S87-90.

14. Thorup J, Cortes D. The incidence of maldecended testes in Denmark. Pediatr Surg Int 1990; 5: 2-5.

15. Kaplan GW. Nomenclature of cryptorchidism. Eur J Pediatr 1993; 152 Suppl. 2: S17-9.

16. Papparella A, Parmeggiani P, Cobellis G, et al. Laparoscopic management of non palpable testes: a multicenter study of the Italian society of videosurgery in infancy. J Pediatr Surg 2005; 40: 696-700.

17. Stowikowska-Hilczer J, Szarras-Czapnik M. Disorders of testicular organogenesis and sex differentiation. In: Male reproductive system. Clinical and experimental studies. Piasecka M (ed.). Pomeranian Medical University, Szczecin 2013; 397-416.

18. Abeyaratne MR, Aherne WA, Scott JES. The vanishing testis. Lancet 1969; 2: 822-4.

19. Sarto GE, Opitz JM. The XY gonadal agenesis syndrome. J Med Genet 1973; 10: 288-93.

20. Bobrow M, Gough MH. Bilateral absence of testes. Lancet 1970; 1: 366-70.

21. Skakkebaek NE, Rajpert-De Meyts E, Main KM. Testicular dysgenesis syndrome: an increasingly common developmental disorder with environmental aspects. Hum Reprod 2001; 16: 972-8.

22. Amann RP, Veeramachaneni DN. Cryptorchidism in common eutherian mammals. Reproduction 2007; 133: 541-61.

23. Berta P, Hawkins JR, Sinclair AH, et al. Genetic evidence equating SRY and the testis-determining factor. Nature 1990; 348: 448-50.

24. Rao PK, Burnett AL. Development of the male reproductive system. In: Clinical Urologic Endocrinology. Principles for Men's Health. Kavoussi PK, Costabile RA, Salonia A (eds). Springer-Verlag, London 2013; 11-24.

25. Hunter J. A description of the situation of the testis in the foetus, with its descent into the scrotum. In: Observations on Certain Parts of the Animal Oeconomy. Hunter J (eds). 1786; 1-26. http://surgicat.rcseng.ac.uk/ media/pdfs/works-v4-p1-19.pdf

26. Josso N, di Clemente N, Gouedard L. Anti-Mullerian hormone and its receptors. Mol Cell Endoc 2001; 179: 25-32.

27. Thonneau P, Bujan L, Multigner L, Mieusset R. Occupational heat exposure and male fertility: a review. Hum Reprod 1998; 13: 2122-5.

28. Hutson JM. A biphasic model for the hormonal control of testicular descent. Lancet 1985; 2: 419-21.

29. Nef S, Parada LF. Hormones in male sexual development. Genes Dev 2000; 14: 3075-86.

30. Zimmermann S, Steding G, Emmen JM, et al. Targeted disruption of the Insl3 gene causes bilateral cryptorchidism. Mol Endocrinol 1999; 13: 681-91.

31. Foresta C, Zuccarello D, Garolla A, Ferlin A. Role of hormones, genes and environment in human cryptorchidism. Endocrin Rev 2008; 29: 560-80.

32. Hutson JM, Hasthorpe S. Testicular descent and cryptorchidism: the state of the art in 2004. J Pediatr Surg 2005; 40: 297-302. 
33. Barteczko KJ, Jacob MI. The testicular descent in human. Origin, development and fate of the gubernaculum Hunteri, processus vaginalis peritonei, and gonadal ligaments. Adv Anat Embryol Cell Biol 2000; 156: III-X, 1-98.

34. Davies TW, Williams DRR, Whitaker RH. Risk factors for undescended testis. Int J Epidemiol 1986; 15: 197-201.

35. Main KM, Mortensen GK, Kaleva MM, et al. Human breast milk contamination with phthalates and alterations in endogenous reproductive hormones in infants three months of age. Environ Health Perspect 2006; 114: $270-6$

36. Thorup J, Cortes D, Petersen BL. The incidence of bilateral cryptorchidism is increased and the fertility potential is reduced in sons born to mothers who have smoked during pregnancy. J Urol 2006; 176: 734-7.

37. Jones IR, Young ID. Familial incidence of cryptorchidism. J Urol 1982; 127: 508-9.

38. Miodek M, Niedzielski J. Anomalies of testis, epididymis and vas deferens in cryptorchid boys. Urol Pol 2001; 54: 63-6.

39. Silva-Ramos M, Oliveira JM, Cabeda JM, Reis A, Soares J, Pimenta A. The CAG repeat within the androgen receptor gene and its relationship to cryptorchidism. Int Braz J Urol 2006; 32: 330-4.

40. Suzuki Y, Sasagawa I, Itoh K, Ashida J, Ogata T. 5alpha-reductase type 2 genes in Japanese males do not appear to be associated with cryptorchidism. Fertil Steril 2002; 78: 330-4.

41. Bertini V, Bertelloni S, Valetto A, Lala R, Foresta C, Simi P. Homeobox HOXA10 gene analysis in cryptorchidism. J Pediatr Endocrinol Metab 2004; 17: 41-5.

42. Wada Y, Okada M, Fukami M, Sasagawa I, Ogata T. Association of cryptorchidism with Gly146Ala polymorphism in the gene for steroidogenic factor-1. Fertil Steril 2006; 85: 787-90.

43. Setchell BP. The Parkes Lecture. Heat and the testis. J Reprod Fertil 1998; 114: 179-94.

44. Mieusset R, Bujan L. The potential of mild testicular heating as a safe, effective and reversible contraceptive method for men. Int J Androl 1994; 17: 186-91.

45. Paduch DA, Niedzielski J. Semen analysis in young man with varicocele: preliminary study. J Urol 1996; 156: 788-90.

46. Paduch DA, Niedzielski J. Repair versus observation in adolescent varicocele: a prospective study. J Urol 1997; 158: 1128-32

47. Ivell R, Hartung S. The molecular basis of cryptorchidism. Mol Hum Reprod 2003; 9: 175-81.

48. Zini A, Abitbol J, Schulsinger D, Goldstein M, Schlegel PN. Restoration of spermatogenesis after scrotal replacement of experimentally cryptorchid rat testis: assessment of germ cell apoptosis and eNOS expression. Urology 1999; 53: n223-7.

49. Huckins C. The spermatogonial stem cell population in adult rats. 3. Evidence for a long-cycling population. Cell Tissue Kinet 1971; 4: 335-49.

50. Hadziselimovic F, Herzog B. The importance of both an early orchidopexy and germ cell maturation for fertility. Lancet 2001; 358: 1156-7.

51. Gracia J, Sánchez Zalabardo J, Sánchez García J, García C, Ferrández A. Clinical, physical, sperm and hormonal data in 251 adults operated on for cryptorchidism in childhood. BJU Int 2000; 85: 1100-3.

52. Cortes D, Thorup JM, Visfeldt J. Cryptorchidism: aspects of fertility and neoplasms. A study including data of 1,335 consecutive boys who underwent testicular bi- opsy simultaneously with surgery for cryptorchidism. Horm Res 2001; 55: 21-7.

53. Hadziselimovic F, Herzog B, Seguchi H. Surgical correc tion of cryptorchism at 2 years: electron microscopic and morphometric investigations. J Pediatr Surg 1975; 10: $19-26$

54. Kollin C, Karpe B, Granholm K, Hesser U, Ritzen EM. Surgical treatment of undescended testes. Testicular growth after randomization to orchidopexy at 9 months or 3 years of age. J Urol 2007; 178: 1589-93.

55. Hadziselimovic F, Hocht B, Herzog B, Buser MW. Infertility in cryptorchidism is linked to the stage of germ cell development at orchidopexy. Horm Res 2007; 68: 46-52.

56. Chung E, Brock GB. Cryptorchidism and its impact on male fertility: a state of art review of current literature. Can Urol Assoc J 2011; 5: 2010-4.

57. Wood HM, Elder JS. Cryptorchidism and testicular cancer: separating fact from fiction. J Urol 2009; 181: 452-61.

58. Skakkebaek NE, Berthelsen JG, Muller J. Carcinoma-in-situ of the undescended testis. Urol Clin North Am 1982 9: 377-85.

59. Swerdlow AJ, Higgins CD, Pike MC. Risk of testicular cancer in cohort of boys with cryptorchidism. BMJ 1997; 314: 1507-11.

60. Harland SJ, Cook PA, Fossa SD, Horwich A, Mead GM, Parkinson MC. Intratubular germ cell neoplasia of the contralateral testis in testicular cancer: defining a high risk group. J Urol 1998; 160: 1353-7.

61. Guminska A, Oszukowska E, Kuzanski W, et al. Less advanced testicular organogenesis is associated with a higher incidence of germ cell neoplasia. Int J Andro 2010; 33: 153-62.

62. Carmignani L, Morabito A, Gadda F, Bozzini G, Rocco F, Colpi GM. Prognostic parameters in adult impalpable ultrasonographic lesions of the testicle. J Urol 2005; 174: 1035-8.

63. Slowikowska-Hilczer J, Romer TE, Kula K. Neoplastic potential of germ cells in relation to disturbances of gonadal organogenesis and changes in karyotype. J Andro 2003, 24: 270-8.

64. Pettersson A, Richiardi L, Nordenskjold A, Kaijser $M$, Akre O. Age at surgery for undescended testis and risk of testicular cancer. N Eng J Med 2007; 356: 1835-41.

65. Slowikowska-Hilczer J, Szarras-Czapnik M, Romer TE, Kula K. High incidence of intratubular germ cell carcinoma in dysgenetic testes of patients with 46,XY karyotype. Aberrations of sex chromosomes are less predictive. In: Andrology of the 21 Century. Robaire B, Chemes $\mathrm{H}$, Morales CR (eds). Medimond Publishing Co, 2001; 409-14.

66. Feldman Wichtel S, Lee PA. Ambiguous genitalia. In: Pediatric endocrinology. 2nd ed. Sperling MA (ed.). WB Saunders, Philadelphia 2002; 111-33.

67. Hack WWM, van der Voort-Doedens LM, Sijstermans K, Meijer RW, Pierik FH. Reduction in the number of orchidopexies for cryptorchidism after recognition of acquired undescended testis and implementation of expectative policy. Acta Paediatrica 2007; 96: 915-8.

68. Kanemoto K, Hayashi Y, Kojima Y, Maruyama T, Ito M, Kohri K. Accuracy of ultrasonography and magnetic resonance imaging in the diagnosis of non-palpable testis. Int J Urol 2005; 12: 668-72.

69. Nguyen HT, Coakley F, Hricak H. Cryptorchidism: strategies in detection. Eur Radiol 1999; 9: 336-43.

70. Niedzielski J, Pisarska K, Przewratil P. The usefulness of testicular atrophy index in the assessment of unde- 
scended testicle - preliminary report. Rocz Akad Med Bialymst 2003; 48: 112-4.

71. Mano R, Livne PM, Nevo A, Sivan B, Ben-Meir D. Testicular torsion in the first year of life - characteristics and treatment outcome. Urology 2013; 82: 1132-7.

72. Deming CL. The evaluation of hormonal therapy in cryptorchidism. J Urol 1952; 68: 354-7.

73. Schapiro B. 25 Years of hormonal treatment of cryptorchidism. Harefuah 1957; 53: 198-9.

74. Kucharski P, Niedzielski J. Neoadjuvant human Chorionic Gonadotropin (hCG) therapy may improve the position of undescended testis: a preliminary report. Cent Eur J Urol 2013; 66: 224-8.

75. Pyorala S, Huttunen NP, Uhari M. A review and metaanalysis of hormonal treatment of cryptorchidism. J Clin Endocrinol Metab 1995; 80: 2795-9.

76. Ong C, Hasthorpe S, Hutson JM. Germ cell development in the descended and cryptorchid testis and the effects of hormonal manipulation. Pediatr Surg Int 2005; 21: 240-54.

77. Bartsch G, Frick J. Therapeutic effects of luteinizing hormone releasing hormone (LH-RH) in cryptorchidism. Andrologia 1974; 6: 197-201

78. Kula K, Walczak-Jedrzejowska R, Slowikowska-Hilczer J, Oszukowska E. Estradiol enhances the stimulatory effect of FSH on testicular maturation and contributes to precocious initiation of spermatogenesis. Mol Cell Endocrinol 2002; 178: 89-97.

79. Lala R, Matarazzo P, Chiabotto P, et al. Early hormonal and surgical treatment of cryptorchidism. J Urol 1997; 157: 1898-901.

80. Annandale T. Case in which a testicle congenitally displaced into the perineum was successfully transferred to the scrotum. Br Med J 1879; 1: 7-8.

81. Perazzo G. Surgical and hormonal therapy of cryptorchidism. Riforma Med 1950; 64: 1051-3.

82. Lattimer JK. Scrotal pouch technique for orchiopexy. J Urol 1957; 78: 628-32.

83. Bianchi A, Squire BR. Transscrotal orchidopexy: orchidopexy revised. Pediatr Surg Int 1989; 4: 189-93.

84. Hay SA, Soliman HA, Rahman AH, Bassiouny IE. Laparoscopic classification and treatment of the impalpable testis. Pediatr Surg Int 1999; 15: 570-2.

85. Fowler R, Stephens FD. The role of testicular vascular anatomy in the salvage of high undescended testes. Aust NZ I Surg 1959; 29: 92-106.

86. Thorup J, Petersen BL, Kvist K, Cortes D. Bilateral vanished testes diagnosed with a single blood sample showing very high gonadotropins (follicle-stimulating hormone and luteinizing hormone) and very low inhibin B. Scand J Urol Nephrol 2011; 45: 425-31.

87. Mengel W, Hienz HA, Sippe WG II, Hecker WC. Studies on cryptorchidism: a comparison of histological findings in the germinative epithelium before and after the second year of life. J Pediatr Surg 1974; 9: 445-50.

88. Bruijnen CJ, Vogels HD, Beasley SW. Review of the extent to which orchidopexy is performed at the optimal age: implications for health services. ANZ J Surg 2008; 78: 1006-9.

89. Docimo SG. The results of surgical therapy for cryptorchidism: a literature review and analysis. J Urol 1995; 154: 1148-52.

90. Thorup J, Haugen S, Kollin C, et al. Surgical treatment of undescended testes. Acta Paediatr 2007; 96: 631-7.

91. Christiansen P, Müller J, Buhl S, et al. Hormonal treatment of cryptorchidism - hCG or GnRH - a multicentre study. Acta Paediatr 1992; 81: 605-8.
92. Hjertkvist M, Lackgren G, Ploen L, Bergh A. Does hCG treatment induce inflammation-like changes in undescended testes in boys? J Pediatr Surg 1993; 28: 254-8.

93. Dunkel L, Taskinen S, Hovatta O, Tilly JL, Wikstrom S. Germ cell apoptosis after treatment of cryptorchidism with human chorionic gonadotropin is associated with impaired reproductive function in the adult. J Clin Invest 1997; 100: 2341-6.

94. Cortes D, Thorup J, Visfeldt J. Hormonal treatment may harm the germ cells in 1 to 3 -year-old boys with cryptorchidism. J Urol 2000; 163: 1290-2.

95. Patel RP, Kolon TF, Huff D, et al. Testicular microlithiasis and antisperm antibodies following testicular biopsy in boys with cryptorchidism. J Urol 2005; 174: 2008-10.

96. Moller H, Cortes D, Engholm G, Thorup J. Risk of testicular cancer with cryptorchidism and with testicular biopsy: cohort study. BMJ 1998; 317: 729. 